\title{
Unobservable Effects in Structural Models of Business Performance
}

\author{
Dirk Annacker \\ Lutz Hildebrandt \\ Institut für Marketing \\ Humboldt-Universität zu Berlin \\ Spandauer Str. 1 \\ D-10178 Berlin, Germany \\ Tel.: ++493020935698 \\ Fax: ++ 493020935675 \\ Email: annacker@wiwi.hu-berlin.de
}




\title{
Unobservable Effects in Structural Models of Business Performance
}

\begin{abstract}
Critiques of the concept of key success factors have raised objections both conceptually and methodologically. From the latter perspective, common research practice is criticized for neglecting the influence of firm-specific, unobservable variables (e.g., management skills). To control for these effects a structural equation approach ("LISREL") to the analysis of panel data is proposed. In an empirical study based on the PIMS annual data base the influence of unobservables on the direct and indirect effects of product quality on profitability is examined. It is shown, how a step by step extension of a basic simultaneous equation model sheds some light on the role unobservable variables play. Even after controlling for persistent unobservable effects product quality and market share remain significant determinants of profitability.
\end{abstract}

\section{Introduction}

Research in strategic management mainly focuses on explaining performance differences between companies. Slightly exaggerated, the essence of strategy research has even been characterized as the "hunt for success factors" (Ghemawat, 1991, p. 3). The normative implications of this research are, that firms should pursue strategies which lead to the development or acquisition of those resources or competencies identified as key success factors in the firm's environment. Various management prescriptions formulated by consultants and academics alike are related to strategies based for example on market share, quality management, customer satisfaction or market orientation as basic determinants of business success.

Although key success factors can be identified in a deductive way (Sousa de Vasconcellos e Sá and Hambrick, 1989) or by doing case studies (e.g., Peters and Waterman, 1982), typically large-scale, multi-industry samples are examined in a cross-sectional style (e.g., Capon, Farley, and Hoenig, 1990). The PIMS program (Buzzell and Gale, 1987) and its vast amount of subsequent studies are exemplary for this type of research. In general, great correspondence exists between empirical research in the classical industrial organisation (IO) tradition and strategy-oriented business studies. The latter have not only borrowed from the methodological toolbox developed in IO research, also their basic design follows closely its structure-conduct-performance paradigm. But, whereas classi- 
cal IO mainly concentrated on the structure component (conduct was only implicit), business-oriented studies naturally are more interested in strategic actions and their performance implications (Porter, 1981).

However, the approach to base the development of firm strategies on empirically identified key success factors has received both conceptual and methodological criticism (Rumelt, Schendel, and Teece, 1991; Ghemawat, 1991; Camerer and Fahey, 1988; Jacobson, 1992). Some groups of management researchers and economists even totally dismiss the idea of key success factors. Assuming that "no general rule for riches" (Rumelt, Schendel, and Teece, 1991, p. 11) - a rule which follows from the equilibrium assumption routinely invoked by economic theory - exists, these researchers doubt that firms can gain supranormal profits by following prescriptions widely known among competing firms. If firms do not face difficulties to implement such strategies than none of them should gain a sustainable competitive advantage - any above average return would be competed away immediately (Barney, 1986).

The "no general rule for riches" appears as a compelling argument against the concept of success factors. So far, this position is to a large extent unchallenged and the great majority of researchers investigating strategy-performance relationships even tends to ignore this critique. Only a few academics have made efforts towards a rebuttal. Boulding and Staelin $(1993,1995)$ develop a conceptual framework which helps to determine the conditions under which general strategic prescriptions (e.g., gaining market share, R\&D expenditures) allow firms to sustain supranormal returns. Other researchers like Grunert and Ellegaard (1993) suppose that key success factors are sufficiently stable at least for a medium-range period of time. They regard the concreteness of a key success factor in terms of the actions necessary to develop the required resources as a major determinant of the time-span by which this factor is able to explain performance differences. In a similar way Mosakowski (1998) argues that the connection between managerial prescriptions and firm performance is not deterministic but to a certain extent stochastic. Proposed key success factors in the first place convey information of a "know what" but not of a "know how" type. Strategic decisions and their implementations based on the same general prescriptions might therefore lead to different firm-specific resources and competencies and thus to different performance levels. Although "rules for riches" at best are transitory, general "rules of chances for riches" (Mosakowski, 1998, p. 1171) may persist over time. From that point of view, research on key success factors can support companies in improving their business performance.

The economic concept of equilibrium also raises questions about the interpretation of relationships between certain strategic actions and business performance revealed in empirical studies (Camerer, 1985; Wensley, 1982). Driving this concept to the extreme, if firms base their decisions on rational expectations (Muth, 1961) incorporating all relevant economic knowledge including even the performance implications of the strategy under study, than all investments into the required resources 
should be properly priced. In this case, no positive effects of, for example, advertising expenditures or market share gains on profits should emerge in a correctly specified model. If one nevertheless finds a positive effect, two basic interpretations are possible. First, one might dismiss the equilibrium assumption and might instead assume that indeed novel knowledge on key success factors has been revealed, a perspective which most researchers engaged in strategy-performance studies would agree with (e.g., Biggadike, 1979). Second, if one is reluctant to suppose that the decision makers were ignorant about the managerial prescription, the question rises what else might be responsible for the performance differences. Here, many possible causes have been put forward, for example superior management quality, private information, a privileged resource position or simply "luck" (e.g., Rumelt, Schendel, and Teece, 1991; Jacobson, 1992). Because these phenomena are to a large extent difficult to measure or even unobservable they have been widely neglected in empirical studies (e.g., Buzzell and Gale, 1987).

In the end, the degree to which decision makers understand the "true" causes of success in their business environment remains largely an empirical question (Rumelt, Schendel and Teece, 1991). This leads to the conclusion that especially those phenomena which are unobservable, like private information or firm specific "invisible assets" (Itami and Roehl, 1987) have to be taken into account when the effect of observed strategic factors is estimated (Jacobson, 1990, 1992).

Fundamental to the issue of controlling for unobservables in empirical studies is the application of an appropriate methodology. Different methods have been proposed which in general have produced different results using the same data (Rumelt and Wensley, 1980; Jacobson and Aaker, 1985; Jacobson, 1988, Jacobson, 1990; Boulding, 1990; Boulding and Staelin, 1990, 1993; Ailawadi, Farris, and Parry, 1999). The substantial interpretations therefore are to a large extent method-dependent. A related problem concerns the distinction between short-term and long-term effects of strategic success factors. For example, the main intension of the PIMS architects has been to explain "strategic", typically long-run performance differences between strategic business units operating in different industries (Buzzell and Gale, 1987; Buzzell this issue; see also Ailawadi, Farris, and Parry, 1993). In contrast, the empirical studies cited above make use of the panel character of the PIMS annual data base to control for the influence of unobservable variables, but thereby explain rather short-term changes of business performance (e.g., Buzzell and Gale, 1987; Buzzell, this issue).

From a managerial perspective, another problem is that unobservable variables have been subsumed under rather broad categories like "management quality" or "luck", which is of no particular help for management when it comes to strategy development. Management research in general is interested in managerial and observable impact factors. As such, for decades a theoretical basis using concepts from the IO-approach seemed most appropriate to guide management decisions. 
However, the debate about unobservable influences also led to the adoption of new paradigms in strategy research.

In the last decade, strategic management has seen the rapid diffusion of the resource-based view of the firm (Wernerfelt, 1984). Based on the fundamental assumption that firms differ (at least to some extent) in their resource endowments, strict advocates of this theory regard firm-specific resources and competencies as the fundamental causes of sustained competitive advantage (e.g., Barney, 1991; Grant, 1991; Peteraf, 1993, Teece, Pisano and Shuen, 1997). Because not every resource is strategically relevant, general characteristics have been developed which qualify a resource (or a team of resources) as the basis for competitive advantage (e.g., Barney, 1991; Peteraf, 1993). Such resources should be valuable and rare and not easily be transferred, imitated or substituted.

If we accept this perspective, the resource-based view offers a rich theoretical foundation for the explanation of - in general unobservable - firm specific factors of success. As such the approach can be seen as an alternative or at least as a supplement to the classical, IO based approaches to explain success even if an important problem until now is insufficiently solved: The resource-based view lacks valid operationalizations of most of its basic concepts (e.g., competencies). Efforts to measure these variables might even destroy their capability to give firms a competitive advantage (Godfrey and Hill, 1995). In fact, the problems identified with the empirical search for observed causes of performance differences also apply to many cross-sectional resource-based studies (Priem and Butler 2001; Rouse and Dällenbach, 1999).

To sum up the discussion, a methodology is required which at least controls for unobservable effects, estimates the impact of controllable and manageable input variables and takes into account strategic planning purposes (Jacobson, 1990). Here the paper offers a methodology based on a structural equation approach to the estimation of econometric panel models. We also take into account the objections mentioned above regarding previous methods for controlling unobservables. The approach starts with a cross-sectional model for pooled data, which reflects the long-term character of strategic variables. This model is extended stepwise to control for unobservable variables which can be distinguished according to their behaviour over time. To show the capabilities of this methodology, a simultaneous equation model of four variables is specified using key hypotheses on the impact of product quality on profitability from the PIMS research (see Phillips, Chang, and Buzzell, 1983; Jacobson, 1988; Hildebrandt and Annacker, 1996).

The remaining parts of the paper are organized as follows. First, we provide a brief state of the art and assessment of different methods to control for unobservable variables in business performance models. Second, we propose a structural equation approach to pooled time-series cross-sectional data in order to control for unobservable variables. With help of a concrete model of the impact of 
product quality on profitability it will be shown, how different types of unobservables can be taken into account by gradually extending a simple baseline model. Third, the methodology is applied to three samples from the PIMS data base, where the specified models are estimated using LISREL. Fourth, we will discuss the implications of our study.

\section{Methods to control for unobservable variables}

In order to control the influence of unobservable variables on the observed relationships between proposed key drivers of success and measures of firm performance, different methods can be used. An obvious approach would be to operationalize selected unobservable variables (e.g., market orientation) in terms of multiple observed indicators (e.g., Jaworski and Kohli, 1993; Narver and Slater, 1990) and to use regression models or structural equation models with latent variables (e.g., Bollen, 1989) to estimate their impact on the directly observed variables in the model. However, besides the difficulties to measure complex firm-specific unobservables like corporate culture or core competencies, for pragmatic reasons this approach is restricted to only a few variables. Alternatively, data envelopment analysis (Charnes, Cooper, and Rhodes, 1978) can be deployed to obtain proxy variables for managerial efficiency in different functional areas (see for example Murthi, Srinivasan, and Kalyanaram, 1996). It still remains an open question to what extent this method captures all relevant invisible assets.

A more comprehensive approach rests on the availability of panel data and has already been applied in previous studies analyzing business performance (e.g., Jacobson, 1990; Boulding and Staelin, 1990, 1993, 1995; Ailawadi, Farris, and Parry, 1999). The large number of unobserved as well as truly unobservable variables (Griliches, 1974) which potentially are correlated with both the observed strategic factors and firm performance is classified according to the temporal characteristics of their influence. Customarily, three types of variables are distinguished and represented by a specific component of an additive error term $u_{i t}$ :

$$
u_{i t}=\mu_{i}+\rho u_{i, t-1}+\varepsilon_{i t}
$$

(1) Firm-specific variables which have a stable effect over the period of analysis, for example corporate culture or management quality, are taken into account by the time-invariant variable $\mu_{i}$. (2)

Other variables whose influence is likewise persistent but dissipating over time (e.g., product innovations or technological know how), are captured by the term $\rho u_{i, t-1}$ if a first-order autoregressive (AR1) process as the most parsimonious representation is supposed. (3) Finally, temporary stochastic shocks (e.g., "luck") whose effects last only one period (e.g., one year) are modelled by the

serially uncorrelated stochastic disturbance $\varepsilon_{i t}$. 
To control simultaneously for the different types of unobservable effects, for example in a linear, single-equation regression

$$
y_{i t}=\beta^{\prime} x_{i t}+u_{i t}
$$

where $x_{i t}$ is a $(K \times 1)$ vector of exogenous variables and $\beta$ a $(K \times 1)$ vector of regression parameters, the following procedure (Boulding and Staelin, 1993) has been proposed. First, a $\rho$ transformation followed by taking first differences eliminates both the serially correlated effects $\rho u_{i, t-1}$ and the time-invariant variables $\mu_{i}$. Let $\Delta x_{i t}:=x_{i t}-x_{i, t-1}$, this leads to the following autoregressive distributed lag (ARDL) model:

$$
\Delta y_{i t}=\rho \Delta y_{i, t-1}+\beta_{1} \Delta x_{i t}+\beta_{2} \Delta x_{i, t-1}+\Delta \varepsilon_{i t}
$$

where the first-order autocorrelation model imposes the restriction $\beta_{2}=-\rho \beta_{1}$. Second, to control for a possible contemporaneous correlation between the moving-average error term $\Delta \varepsilon_{i t}$ and the explanatory variables, values lagged at least two periods (levels or differences) can be used as instruments in a 2SLS estimation of equation (3).

Although formally the described approach represents a valid method to control for unobservable variables, it should be pointed out, that the required transformations fundamentally alter the model and its intepretation. As can be seen from equation (3), year-to-year changes of strategic factors are related to year-to-year changes in performance (e.g., ROI). If one assumes that long-term and shortterm effects differ, this means that by using difference data only short-term effects of strategic factors are examined. Only in this context stochastic effects might play an important role in the relationships between key factors of success and firm performance. If the researcher is instead concerned with the strategic and therefore long-term implications of key success factors, temporary stochastic shocks might be neglected. From this perspective it seems justified to focus on the control of time-invariant and serially correlated unobservable effects.

Meanwhile a large body of econometric literature (e.g., Hsiao, 1986; Baltagi, 1995) exists to help researchers in specifying panel models and major statistical software packages (e.g., SAS) provide special procedures for the estimation of such models. Alternatively, a structural equation approach ("LISREL"), whose application in econometric panel studies has already been proposed in the late seventies (Jöreskog, 1978), can be used. This approach, however, has largely been ignored in economics and business research (for an exception see Lillard and Willis, 1978; Hildebrandt and Annacker, 1996) although it offers much greater flexibility in the specification of panel models, including the integration of measurement models. We will now present how LISREL (Jöreskog and Sörbom, 1996) can be specified to control for the biasing influence of different types of unobserved variables in a structural equation model. 


\section{The Conceptual Model and Extensions Controlling for Unobservables}

\subsection{Baseline Model}

In order to assess the impact of unobservable or simply unobserved variables on the relationships between perceived product quality, profitability and the intervening variables market share and direct cost we start with a baseline model (BM) in which their influence is completely ignored. In this cross-sectional model return on investment $(R O I)$ is specified as a function of the strategic variables product quality (QUA) and market share (MS) as well as relative direct cost (COST).

Direct cost are determined by product quality and also by market share, which in turn is driven by product quality. For this simultaneous equation model we assume that the disturbances are uncorrelated both over time and across equations (note that specifying free contemporaneous correlations between the disturbances would make the model underidentified):

$$
\begin{aligned}
R O I_{i t} & =\beta_{1} \operatorname{COST}_{i t}+\beta_{2} M S_{i t}+\gamma_{1} Q U A_{i t}+\varepsilon_{1 i t}, \\
C O S T_{i t} & =\beta_{3} M S_{i t}+\gamma_{2} Q U A_{i t}+\varepsilon_{2 i t}, \\
M S_{i t} & =\gamma_{3} Q U A_{i t}+\varepsilon_{3 i t}, \\
& \quad i=1, \ldots, N, \quad t=1, \ldots, T,
\end{aligned}
$$

where

$$
E\left(\varepsilon_{g i t} \varepsilon_{g^{\prime} i^{\prime} t^{\prime}}\right)=\left\{\begin{array}{cl}
\sigma_{\varepsilon_{s}}^{2} & \text { if } g=g^{\prime}, i=i^{\prime}, t=t^{\prime}, \\
0 & \text { else. }
\end{array}\right.
$$

To control for the persistent effects attributable to unobservables, this baseline model is gradually extended by incorporating different error components.

\subsection{Model Extensions}

\subsubsection{Controlling for time-invariant effects}

As a first step, we exclusively control for unobserved persistent characteristics of the SBUs hypothesized to be invariant over time (e.g., management quality or customer-oriented culture). Although one might expect that product quality is correlated with these individual effects we start with a random effects model (RE) under the assumption of no such correlation. The random individual effects $\mu_{g i}$ for each equation $g(g=1, \ldots, 3)$ are represented in the LISREL model by additional latent variables for which no measurement relations exist (see Jöreskog, 1978). In contrast to the time-varying disturbances $\varepsilon_{g i t}$ we assume that these effects are correlated with each other. 
As is well known from the panel data literature, the consistency of the model parameters in the RE model hinges on the validity of the assumption that the exogenous variables are indeed uncorrelated with the individual effects. If the latter is not the case, a fixed-effects specification is typically choosen (e.g., Hsiao, 1986). A convenient way followed predominantly in previous studies on business performance is to eliminate these persistent effects by taking first differences of the data (e.g., Boulding and Staelin, 1990; Ailawadi, Farris, and Parry, 1999). As an alternative specification which controls for a possible correlation between individual effects and exogenous variables we propose a modified random effects model, hereafter referred to as the RECEV (random effects correlated with exogenous variables) model. Following Mundlak (1978), we assume that the conditional expectation of the random effects $E\left(\mu_{g i} \mid x_{i t}\right)$ can be approximated by a linear reduced form:

$$
\mu_{g i}=\sum_{t=1}^{T} \pi_{g t}^{\prime} x_{i t}+\omega_{g i}
$$

where $\omega_{g i} \sim N\left(0, \sigma_{\omega_{g}}^{2}\right)$. Augmenting the RE model by the reduced form equations for the individual effects, this model can be written as follows:

$$
\begin{gathered}
R O I_{i t}=\beta_{1} \operatorname{COST}_{i t}+\beta_{2} M S_{i t}+\gamma_{1} Q U A_{i t}+\mu_{1 i}+\varepsilon_{1 i t}, \\
C O S T_{i t}=\beta_{3} M S_{i t}+\gamma_{2} Q U A_{i t}+\mu_{2 i}+\varepsilon_{2 i t}, \\
M S_{i t}=\gamma_{3} Q U A_{i t}+\mu_{3 i}+\varepsilon_{3 i t}, \\
\mu_{1 i}=\sum_{t=1}^{T} \pi_{1 t} Q U A_{i t}+\omega_{1 i}, \\
\mu_{2 i}=\sum_{t=1}^{T} \pi_{2 t} Q U A_{i t}+\omega_{2 i}, \\
\mu_{3 i}=\sum_{t=1}^{T} \pi_{3 t} Q U A_{i t}+\omega_{3 i}, \\
E\left(\omega_{g i} \omega_{g^{\prime} i^{\prime}}\right)=\left\{\begin{array}{ll}
\sigma_{\omega_{g}}^{2} & \text { if } g=g^{\prime}, i=i^{\prime} \\
\sigma_{\omega_{g g^{\prime}}} & \text { if } g \neq g^{\prime}, i=i^{\prime}, E\left(\varepsilon_{g i t} \varepsilon_{g^{\prime} i^{\prime}}\right)=\left\{\begin{array}{c}
\sigma_{\varepsilon_{g}}^{2} \\
0
\end{array} \quad \text { if } g=g^{\prime}, i=i^{\prime}, t=t^{\prime},\right. \\
0 & \text { else }
\end{array} \quad t=1, \ldots, T,\right.
\end{gathered}
$$

The RECEV model has several advantages over the first difference (FD) model. In contrast to the FD model time-invariant observed variables can be included. In addition, the model allows a flexible specification of correlations between the individual effects and selected exogenous variables. Because the RE model is nested in the RECEV model, hypotheses about correlations between the individual effects and all or specific exogenous variables can be easily tested by $\chi^{2}$ difference tests. To test these hypotheses for the FD model the Hausman test has to be used, which relies on 
the differences in the parameter estimates between the random and the fixed effects specification (Hausman, 1978).

\subsubsection{Controlling for autoregressive effects}

As a further extension, we assume that besides the time-invariant individual effects serially correlated unobserved variables are present and correlated with the explanatory variables. The latter effects can be eliminated by $\rho$-differencing the data (e.g., Boulding and Staelin, 1993, 1995). This leads to the following autoregressive distributed lag (ARDL) specification of the simultaneous equation model:

$$
\begin{aligned}
R O I_{i t}= & \rho_{1} R O I_{i, t-1}+\beta_{1} \operatorname{COST}_{i t}+\beta_{2} \operatorname{COST}_{i, t-1}+\beta_{3} M S_{i t}+\beta_{4} M S_{i, t-1}+\gamma_{1} Q U A_{i t} \\
& +\gamma_{2} Q U A_{i, t-1}+\mu_{1 i}^{*}+\varepsilon_{1 i t}, \\
C O S T_{i t}= & \rho_{2} \operatorname{COST}_{i, t-1}+\beta_{5} M S_{i t}+\beta_{6} M S_{i, t-1}+\gamma_{3} Q U A_{i t}+\gamma_{4} Q U A_{i, t-1}+\mu_{2 i}^{*}+\varepsilon_{2 i t}, \\
M S_{i t}= & \rho_{3} M S_{i, t-1}+\gamma_{5} Q U A_{i t}+\gamma_{6} Q U A_{i, t-1}+\mu_{3 i}^{*}+\varepsilon_{3 i t}, \\
\mu_{1 i}^{*}= & \pi_{1} R O I_{i 1}+\pi_{2} \operatorname{COST}_{i 1}+\pi_{3} M S_{i 1}+\sum_{t=1}^{T} \pi_{4 t} Q U A_{i t}+\omega_{1 i}, \\
\mu_{2 i}^{*}= & \pi_{5} R O I_{i 1}+\pi_{6} \operatorname{COST}_{i 1}+\pi_{7} M S_{i 1}+\sum_{t=1}^{T} \pi_{8 t} Q U A_{i t}+\omega_{2 i}, \\
\mu_{3 i}^{*}= & \pi_{9} R O I_{i 1}+\pi_{10} \operatorname{COST}_{i 1}+\pi_{11} M S_{i 1}+\sum_{t=1}^{T} \pi_{12 t} Q U A_{i t}+\omega_{3 i}, \\
& i=1, \ldots, N, \quad t=2, \ldots, T
\end{aligned}
$$

where $\mu_{g i}^{*}=\left(1-\rho_{g}\right) \mu_{g i}$, and

$$
E\left(\omega_{g i} \omega_{g^{\prime} i^{\prime}}\right)= \begin{cases}\sigma_{\omega_{g}}^{2} & \text { if } g=g^{\prime}, i=i^{\prime} \\
\sigma_{\omega_{g g^{\prime}}} & \text { if } g \neq g^{\prime}, i=i^{\prime}, \quad E\left(\varepsilon_{g i t} \varepsilon_{g^{\prime} i^{\prime} t^{\prime}}\right)=\left\{\begin{array}{cl}
\sigma_{\varepsilon_{g}}^{2} & \text { if } g=g^{\prime}, i=i^{\prime}, t=t^{\prime}, \\
0 & \text { else }
\end{array}\right. \text { else. }\end{cases}
$$

The serial correlation hypothesis imposes non-linear restrictions on the coefficients for the lagged explanatory variables (e.g., $\beta_{2}=-\rho_{1} \beta_{1}$ or $\gamma_{2}=-\rho_{1} \gamma_{1}$ ), since it is assumed that the explanatory variables only have a current effect on the dependent variables. The autoregressive effects of the lagged dependent variables in each equation therefore exclusively reflect the influence of serially correlated unobserved variables which influence business performance and possibly also the explanatory variables. Because the autocorrelation model with individual effects (hereafter noted as AR1-RECEV) is nested in the unrestricted ARDL model (7), $\chi^{2}$ difference tests (likelihood ratio tests) can be used to examine if the non-linear restrictions of this model hold. 
A rival hypothesis states that the explanatory variables influence unobserved variables, for example "goodwill", which in turn affect the dependent variables, for example profitability. In this state dependence model the indirect, lagged influence of strategic factors like product quality via some unobserved state variables is reflected in the autoregression coefficient of the lagged dependent variable, which is in sharp contrast to its interpretation in the autocorrelation model. This gives rise to the restriction that the coefficient for the lagged explanatory variable is zero in the ARDL model (7) (for a discussion of both the serial correlation and the state dependence model see Jacobson, 1990; Ailawadi, Farris, and Parry, 1993).

\section{Empirical Study}

\subsection{Data}

The performance of the LISREL approach to control for unobservables is demonstrated in an empirical analysis based on the PIMS SPIYR annual database. Data for those strategic business units (SBU) have been sampled which at least provide information for six consecutive years. This results in a pooled sample of $1141 \mathrm{SBU}$. In order to control for differences which can be attributed to the industry type a strategic business unit belongs to, we analyse the following three samples (service and distribution businesses are excluded from the analysis because of small sample size):

- (other) industrial goods $(N=608)$

- capital goods $(N=187)$

- $\quad$ consumer goods $(N=311)$

The sample "other industrial goods" consists of business units which manufacture raw and semifinished materials, components, and industrial supplies.

\subsection{Analysis}

\subsubsection{Baseline model}

The maximum likelihood method implemented in LISREL 8 (Jöreskog and Sörbom, 1996) has been used to estimate the model parameters. Starting with the cross-sectional baseline model (4), the overall fit measures (see Table 1) show that the fit to the annual data in the different samples is extremely bad (in addition to the highly significant $\chi^{2}$ statistic the fit index RMSEA is considerably above the cut-off value of .05 (Browne and Cudeck, 1993; Hu and Bentler, 1999) and both CFI and TLI are far below the threshold value of .95 (Hu and Bentler, 1998); for an overview of the interpretation of fit indices in structural equation modelling see for example Bagozzi and Baumgartner, 1994). Strictly speaking, this renders any interpretation of the model parameters 
meaningless. For comparisons with subsequent models controlling for unobservable variables we will nevertheless shortly discuss the estimated effects of product quality. In all samples the direct effect of product quality on market share is positive. Since market share increases ROI both directly and indirectly (via reducing relative direct cost) the positive direct impact of quality on profitability is further increased by this indirect effect. The positive effect is partly offset by higher direct cost accompanying higher product quality for SBUs operating in the capital goods industry. Overall, these findings closely mirror the results of preceding cross-sectional studies on how quality influences profitability (e.g., Phillips, Chang, and Buzzell, 1983).

\begin{tabular}{|c|c|c|c|}
\hline Parameter & $\begin{array}{l}\text { Industrial } \\
\text { Goods }\end{array}$ & $\begin{array}{l}\text { Capital } \\
\text { Goods }\end{array}$ & $\begin{array}{l}\text { Consumer } \\
\text { Goods }\end{array}$ \\
\hline$\gamma_{R O I, Q U A}$ & $\begin{array}{l}.239 * * * \\
(.015)\end{array}$ & $\begin{array}{l}.097 * * * \\
(.023)\end{array}$ & $\begin{array}{l}.084 * * * \\
(.020)\end{array}$ \\
\hline$\gamma_{M S, Q U A}$ & $\begin{array}{l}.231 * * * \\
(.010)\end{array}$ & $\begin{array}{l}.135 * * * \\
(.019)\end{array}$ & $\begin{array}{l}.217 * * * \\
(.013)\end{array}$ \\
\hline$\gamma_{C O S T, Q U A}$ & $\begin{array}{l}.001 \\
(.005)\end{array}$ & $\begin{array}{l}.030 * * * \\
(.008)\end{array}$ & $\begin{array}{c}.006 \\
(.006)\end{array}$ \\
\hline$\beta_{R O I, M S}$ & $\begin{array}{l}.274 * * * \\
(.024)\end{array}$ & $\begin{array}{l}.212 * * * \\
(.037)\end{array}$ & $\begin{array}{l}.491 * * * \\
(.033)\end{array}$ \\
\hline$\beta_{C O S T, M S}$ & $\begin{array}{l}-.052 * * * \\
(.008)\end{array}$ & $\begin{array}{l}-.116^{* * * *} \\
(.013)\end{array}$ & $\begin{array}{l}-.075^{* * * *} \\
(.009)\end{array}$ \\
\hline$\beta_{R O I, C O S T}$ & $\begin{array}{l}-.401 * * * \\
(.052)\end{array}$ & $\begin{array}{l}-.632 * * * \\
(.084)\end{array}$ & $\begin{array}{l}-.532 * * * \\
(.081)\end{array}$ \\
\hline \multicolumn{4}{|l|}{$\begin{array}{l}\text { Fit } \\
\text { Measures }\end{array}$} \\
\hline$\chi_{(d . f .)}^{2}$ & $19,315_{(270)}$ & $5,538_{(270)}$ & $10,137_{(270)}$ \\
\hline RMSEA & .333 & .320 & .336 \\
\hline$p_{\text {RMSEA }}$ & .000 & .000 & .000 \\
\hline CFI & .290 & .312 & .300 \\
\hline NFI & .287 & .302 & .295 \\
\hline $\mathrm{RMR}^{s}$ & .311 & .331 & .332 \\
\hline
\end{tabular}

Table 1: Parameter estimates and fit measures for the baseline model BM

\subsubsection{Controlling for time-invariant effects}

As a first step in investigating the role unobservable/unobserved variables play in the relationships between the observed variables in our model we control for time-invariant effects. Because we would like to test the assumption that perceived product quality is correlated with these unobserved effects, we first estimate a random-effects model RE under the assumption that the individual effects $\mu_{R O I}, \mu_{M S}$ and $\mu_{C O S T}$ are correlated with each other but not with quality. 
Compared to the baseline model the overall fit (see Table 2) has considerably improved, a clear indication that unobserved individual effects exist. Nevertheless, the fit measures indicate that the model is still clearly rejected by the data.

\begin{tabular}{|c|c|c|c|}
\hline Parameter & $\begin{array}{l}\text { Industrial } \\
\text { Goods }\end{array}$ & $\begin{array}{l}\text { Capital } \\
\text { Goods }\end{array}$ & $\begin{array}{l}\text { Consumer } \\
\text { Goods }\end{array}$ \\
\hline$\gamma_{R O I, Q U A}$ & $\begin{array}{l}.162 * * * \\
(020)\end{array}$ & $\begin{array}{l}.060 * * \\
(030)\end{array}$ & $\begin{array}{l}.094 * * * \\
(026)\end{array}$ \\
\hline$\gamma_{M S, Q U A}$ & $\begin{array}{l}.069 * * * \\
(.006)\end{array}$ & $\begin{array}{l}.088 * * * \\
(.011)\end{array}$ & $\begin{array}{l}.055^{* * *} \\
(.007)\end{array}$ \\
\hline$\gamma_{C O S T, Q U A}$ & $\begin{array}{l}-.023 * * * \\
(.004)\end{array}$ & $\begin{array}{l}-.001 \\
(.007)\end{array}$ & $\begin{array}{l}-.036 * * * \\
(.006)\end{array}$ \\
\hline$\beta_{R O I, M S}$ & $\begin{array}{l}.472 * * * \\
(.071)\end{array}$ & $\begin{array}{l}.528 * * * \\
(.110)\end{array}$ & $\begin{array}{l}.638 * * * \\
(.103)\end{array}$ \\
\hline$\beta_{C O S T, M S}$ & $\begin{array}{l}-.031 * * * \\
(.012)\end{array}$ & $\begin{array}{l}-.005 \\
(.023)\end{array}$ & $\begin{array}{l}-.046 * * \\
(.020)\end{array}$ \\
\hline$\beta_{R O I, C O S T}$ & $\begin{array}{l}-.425 * * * \\
(.108)\end{array}$ & $\begin{array}{l}-.681 * * * \\
(.155)\end{array}$ & $\begin{array}{l}-.873 * * * \\
(.128)\end{array}$ \\
\hline \multicolumn{4}{|l|}{$\begin{array}{l}\text { Fit } \\
\text { Measures }\end{array}$} \\
\hline$\chi_{(d . f .)}^{2}$ & $4,445_{(264)}$ & $1,465_{(264)}$ & $2,197_{(264)}$ \\
\hline RMSEA & .169 & .161 & .166 \\
\hline$p_{\text {RMSEA }}$ & .000 & .000 & .000 \\
\hline CFI & .844 & .843 & .863 \\
\hline NFI & .836 & .815 & .847 \\
\hline $\mathrm{RMR}^{s}$ & .113 & .069 & .117 \\
\hline
\end{tabular}

Table 2: Parameter estimates and fit measures for the RE model

To control for a possible correlation between product quality and the time-invariant unobserved effects we estimated two different specifications - the RECEV and the FD model. Although some of the fit indices for these models (see Table 3) reach levels indicating at least a moderate fit (RMSEA for the FD model and $\mathrm{RMR}^{\mathrm{s}}$ for the RECEV model), overall these static models again do not seem to provide an adequate representation of the system under study.

To test whether time-invariant effects simultaneously influence both product quality and the endogenous variables in the model, we performed several $\chi^{2}$ difference tests (see Table 4). An overall test results from a comparison between the RE and the RECEV model. Restricting all parameters of the reduced form equations for the individual effects in the RECEV model to zero leads to a significant drop in fit for industrial and consumer goods. Whereas product quality seems to be correlated with the persistent effects in these industries, this does not hold true for capital goods. Be- 
sides an overall test, each possible correlation between quality and the different time-invariant effects has been tested individually by restricting the RECEV model appropriately. With one exception product quality is correlated with the unobserved effects in the industry and consumer goods samples (quality is not related to $\mu_{R O I}$ for consumer goods). A completely different picture emerges for capital goods. Surprisingly, quality is not correlated with any of the individual effects in this type of business.

\begin{tabular}{|c|c|c|c|c|c|c|}
\hline \multirow[b]{2}{*}{ Parameter } & \multicolumn{2}{|c|}{$\begin{array}{l}\text { Industrial } \\
\text { Goods }\end{array}$} & \multicolumn{2}{|c|}{$\begin{array}{l}\text { Capital } \\
\text { Goods }\end{array}$} & \multicolumn{2}{|c|}{$\begin{array}{c}\text { Consumer } \\
\text { Goods }\end{array}$} \\
\hline & RECEV & FD & RECEV & FD & RECEV & FD \\
\hline$\gamma_{R O I, Q U A}$ & $\begin{array}{l}.108 * * * \\
(026)\end{array}$ & $.102 * * *$ & $\begin{array}{l}.051 \\
(038)\end{array}$ & $\begin{array}{l}.024 \\
(045)\end{array}$ & $.116^{* * *}$ & $.089 * *$ \\
\hline & $.057 * * *$ & $.027 * * *$ & $.084 * * *$ & $.072 * * *$ & $.046^{* * *}$ & $.032 * * *$ \\
\hline$\gamma_{M S, Q U A}$ & $(.007)$ & $(.007)$ & $(.011)$ & $(.013)$ & $(.008)$ & $(.008)$ \\
\hline$\gamma_{C O S T, Q U A}$ & $-.026 * * *$ & $-.021 * * *$ & -.005 & -.003 & $-.046 * * *$ & $-.043 * * *$ \\
\hline & $(.004)$ & $(.005)$ & $(.008)$ & $(.008)$ & $(.006)$ & $(.007)$ \\
\hline$\beta_{R O I, M S}$ & $.466 * * *$ & $.590 * * *$ & $.528 * * *$ & $.672 * * *$ & $.640 * * *$ & $.801 * * *$ \\
\hline & $(.071)$ & $(.082)$ & $(.110)$ & $(.112)$ & $(.103)$ & $(.114)$ \\
\hline$\beta_{C O S T, M S}$ & $-.031 * * *$ & -.020 & -.005 & -.001 & $-.047 * *$ & -.031 \\
\hline & $(.012)$ & $(.012)$ & $(.023)$ & $(.019)$ & $(.020)$ & $(.020)$ \\
\hline$\beta_{R O I, C O S T}$ & $\begin{array}{l}-.429 * * * \\
(.108)\end{array}$ & $\begin{array}{l}-.442 * * * \\
(.121)\end{array}$ & $\begin{array}{l}-.682^{* * * *} \\
(.155)\end{array}$ & $\begin{array}{l}-.583 * * * \\
(.179)\end{array}$ & $\begin{array}{l}-.869 * * * \\
(.128)\end{array}$ & $\begin{array}{l}-.711 * * * \\
(.144)\end{array}$ \\
\hline \multicolumn{7}{|l|}{$\begin{array}{l}\text { Fit } \\
\text { measures }\end{array}$} \\
\hline$\chi^{2}$ & 4,372 & 604 & 1,461 & 421 & 2,150 & 419 \\
\hline d.f. & 261 & 183 & 261 & 183 & 261 & 183 \\
\hline RMSEA & .169 & .063 & .162 & .076 & .166 & .064 \\
\hline$p_{\text {RMSEA }}$ & .000 & .000 & .000 & .000 & .000 & .003 \\
\hline CFI & .847 & .216 & .843 & .277 & .866 & .342 \\
\hline NFI & .839 & .169 & .816 & .189 & .851 & .236 \\
\hline $\mathrm{RMR}^{\mathrm{s}}$ & .040 & .076 & .059 & .108 & .043 & .089 \\
\hline
\end{tabular}

Table 3: Parameter estimates and fit measures for the RECEV and FD model

In comparison to the baseline model, the most striking result of the RECEV/FD specifications is a reversal in sign for the quality-cost link. Quality seems to have a significant negative influence on direct cost for the industrial and consumer goods once unobserved individual effects are taken into account. However, in contrast to this substantial interpretation this finding has elsewhere been described as merely an artifact which results from the measurement procedure for product quality in the PIMS project (Boulding, 1992; Boulding and Staelin, 1993). Overall, the direct effects of product quality on ROI and MS are lower, except for the impact on ROI in the consumer goods industry. Therefore, it can be concluded that time-invariant unobservable effects increase ROI, market share and also direct cost for business units offering products with superior product quality. 


\begin{tabular}{|c|c|c|c|c|c|}
\hline Competing models & $\chi^{2}$ & d.f. & $\Delta \chi^{2}$ & $\Delta$ d.f. & $p$ \\
\hline \multicolumn{6}{|l|}{ Industrial Goods } \\
\hline RECEV & 4372.25 & 261 & - & - & - \\
\hline $\operatorname{RECEV} \backslash_{\left(\mu_{R O I}-Q U A\right)}$ & 4377.65 & 262 & 5.40 & 1 & .020 \\
\hline $\operatorname{RECEV\backslash } \backslash_{\left(\mu_{M S}-Q U A\right)}$ & 4427.57 & 262 & 55.32 & 1 & .000 \\
\hline $\operatorname{RECEV} \backslash_{\left(\mu_{C O S T}-Q U A\right)}$ & 4376.63 & 262 & 4.38 & 1 & .036 \\
\hline RE & 4444.99 & 264 & 72.74 & 3 & .000 \\
\hline \multicolumn{6}{|l|}{ Capital Goods } \\
\hline RECEV & 1461.33 & 261 & - & - & - \\
\hline $\operatorname{RECEV\backslash } \backslash_{\left(\mu_{R O I}-Q U A\right)}$ & 1461.34 & 262 & .01 & 1 & .920 \\
\hline $\operatorname{RECEV\backslash } \backslash_{\left(\mu_{M S}-Q U A\right)}$ & 1462.80 & 262 & 1.47 & 1 & .225 \\
\hline $\operatorname{RECEV} \backslash_{\left(\mu_{C O S T}-Q U A\right)}$ & 1462.50 & 262 & 1.17 & 1 & .279 \\
\hline RE & 1465.03 & 264 & 3.70 & 3 & .296 \\
\hline \multicolumn{6}{|l|}{\begin{tabular}{|l|} 
Consumer Goods \\
\end{tabular}} \\
\hline RECEV & 2149.56 & 261 & - & - & - \\
\hline $\operatorname{RECEV} \backslash_{\left(\mu_{R O I}-Q U A\right)}$ & 2151.46 & 262 & 1.90 & 1 & .168 \\
\hline $\operatorname{RECEV\backslash } \backslash_{\left(\mu_{M S}-Q U A\right)}$ & 2179.90 & 262 & 30.34 & 1 & .000 \\
\hline $\operatorname{RECEV} \backslash_{\left(\mu_{C O S T}-Q U A\right)}$ & 2162.10 & 262 & 12.54 & 1 & .000 \\
\hline $\mathrm{RE}$ & 2197.06 & 264 & 47.50 & 3 & .000 \\
\hline
\end{tabular}

Table 4: $\chi^{2}$ difference tests for uncorrelatedness between product quality and time-invariant unobservables

If a static model with time-invariant individual effects were an adequate representation of the quality impact on profitability, one would expect that both the RECEV and the FD model would produce similar estimates. However, there are some noticeable differences between the parameters of both models, especially with respect to the market share effect on direct costs. Whereas in the RECEV model this effect remains significant except for capital goods businesses, in the FD model it vanishes completely in all three samples. Because differencing the data to a certain extent already eliminates the bias caused by autocorrelated unobservable variables (this effect increases the higher the autocorrelation), this might be a reasonable explanation for this effect. In a final step, we therefore control for both time-invariant and autocorrelated unobserved effects.

\subsubsection{Controlling for autoregressive effects}

Judged by conventional cutoff values in structural equation modelling (e.g., Hu and Bentler, 1999), 
the overall fit for the unconstrained estimation of the ARDL model (7) is quite good (see Table 5). However, the hypothesis that the influence of unobservable variables is properly captured solely by a serial correlation model is challenged by these results. Already a closer inspection shows that the estimated coefficients for the lagged explanatory variables in part differ noticeably from their theoretical values which are derived from the restrictions of the serial correlation model (see the calculated values in Table 5). For example, the calculated effects of lagged quality on market share $\left(\gamma_{M S, Q U A_{-1}}\right)$ are several times bigger (in absolute values) than the estimated parameters (e.g., -.028 vs. -.004 in the consumer goods sample) and for capital goods the coefficient, albeit not significant, has even the "wrong" sign (.009 instead of -.042). Likewise, the parameter for lagged market share in the cost equation $\left(\gamma_{\operatorname{COST,MS_{-1}}}\right)$ is significantly positive for industrial goods (.033), whereas the serial correlation model predicts a negative coefficient (-.011).

Because a mere comparison between estimated and theoretical values does not allow a final judgement of the adequacy of a serial correlation model, we performed statistical tests based on the $\chi^{2}$ differences between the unrestricted ARDL model (7) and various restricted models. As one might expect given the findings above, a reestimation of the ARDL model under the complete set of nonlinear restrictions imposed by a serial correlation specification (AR1-RECEV model) led to a significant decrease in fit ( $\alpha=.05$ ) for all samples (see Table 6 ). In addition, the hypothesis of a serial correlation model has been tested separately for each endogenous variable. The results varied considerably for the three samples and will now be discussed in some detail with respect to the quality effect on ROI and market share (for direct cost there is almost no change in the parameter estimates compared to the RECEV model).

With respect to ROI, the serial correlation model holds for SBUs operating in the industrial goods and the capital goods industry but not for consumer goods (see the tests for AR1-RECEV ${ }_{R O I}$ in Table 6). From a substantial point of view, controlling for serially correlated effects in addition to time-invariant unobservables in the former industries only marginally alters the results for the direct effect of product quality on profitability (see Tables 3 and 5). 


\begin{tabular}{|c|c|c|c|c|c|c|}
\hline \multirow{2}{*}{$\begin{array}{l}\text { Parameter } \\
\gamma_{\text {ROI,QUA }}\end{array}$} & \multicolumn{2}{|c|}{$\begin{array}{l}\text { Industrial } \\
\text { Goods } \\
\text { calc. }^{a} \\
\text { val. }\end{array}$} & \multicolumn{2}{|c|}{$\begin{array}{l}\text { Capital } \\
\text { Goods } \\
\text { calc. } \\
\text { val. }\end{array}$} & \multicolumn{2}{|c|}{$\begin{array}{l}\text { Consumer } \\
\text { Goods } \\
\text { calc. } \\
\text { val. }\end{array}$} \\
\hline & $\begin{array}{l}.115^{* * * *} \\
(.038)\end{array}$ & & $\begin{array}{l}.024 \\
(.053)\end{array}$ & & $\begin{array}{l}.035 \\
(.044)\end{array}$ & \\
\hline $\begin{array}{l}\gamma_{R O I, Q U A_{-1}} \\
\gamma_{M S, Q U A}\end{array}$ & $\begin{array}{l}-.026 \\
(.040) \\
.018^{* *} \\
(.009)\end{array}$ & -.078 & $\begin{array}{l}.073 \\
(.056) \\
.066 * * * \\
(.015)\end{array}$ & -.015 & $\begin{array}{l}.014 \\
(.046) \\
.037 * * * \\
(.010)\end{array}$ & -.019 \\
\hline$\gamma_{M S, Q U A_{-1}}$ & $\begin{array}{l}-.007 \\
(.010)\end{array}$ & -.017 & $\begin{array}{l}.009 \\
(.017)\end{array}$ & -.042 & $\begin{array}{l}-.004 \\
(.011)\end{array}$ & -.028 \\
\hline$\gamma_{C O S T, Q U A}$ & $\begin{array}{l}-.027 * * * \\
(.006)\end{array}$ & & $\begin{array}{l}-.005 \\
(.010)\end{array}$ & & $\begin{array}{l}-.051 * * * \\
(.008)\end{array}$ & \\
\hline$\gamma_{C O S T, Q U A_{-1}}$ & $\begin{array}{l}.013 * * \\
(.006)\end{array}$ & .027 & $\begin{array}{l}-.003 \\
(.011)\end{array}$ & .005 & $\begin{array}{l}.029 * * * \\
(.009)\end{array}$ & .046 \\
\hline$\beta_{R O I, M S}$ & $\begin{array}{l}.662 * * * \\
(.098)\end{array}$ & & $\begin{array}{l}.635^{* * *} \\
(.135)\end{array}$ & & $\begin{array}{l}.709 * * * \\
(.132)\end{array}$ & \\
\hline$\beta_{R O I, M S_{-1}}$ & $\begin{array}{l}-.596^{* * * *} \\
(.100)\end{array}$ & -.451 & $\begin{array}{l}-.507 * * * \\
(.131)\end{array}$ & -.391 & $\begin{array}{l}-.618 * * * \\
(.129)\end{array}$ & -.376 \\
\hline$\beta_{C O S T, M S}$ & $\begin{array}{l}.011 \\
(.016)\end{array}$ & & $\begin{array}{l}.014 \\
(.026)\end{array}$ & & $\begin{array}{l}-.020 \\
(.025)\end{array}$ & \\
\hline $\begin{array}{l}\beta_{C O S T, M S_{-1}} \\
\beta_{R O I, C O S T}\end{array}$ & $\begin{array}{l}.033 * * \\
(.015) \\
-.431 * * * \\
(.144)\end{array}$ & -.011 & $\begin{array}{l}.016 \\
(.024) \\
-.549 * * * \\
(.210)\end{array}$ & -.014 & $\begin{array}{l}.024 \\
(.024) \\
-.799 * * * \\
(.164)\end{array}$ & .018 \\
\hline$\beta_{R O I, \operatorname{COST}_{-1}}$ & $\begin{array}{l}.343^{* *} \\
(.144)\end{array}$ & .294 & $\begin{array}{l}.163 \\
(.212)\end{array}$ & .338 & $\begin{array}{l}.088 \\
(.166)\end{array}$ & .423 \\
\hline$\rho_{R O I}$ & $.681 * * *$ & & $.616^{* * *}$ & & $.530 * * *$ & \\
\hline$\rho_{M S}$ & $.964 * * *$ & & $.640 * * *$ & & $.755 * * *$ & \\
\hline$\rho_{\operatorname{COST}}$ & $.988 * * *$ & & $.969 * * *$ & & $.897 * * *$ & \\
\hline \multicolumn{7}{|l|}{$\begin{array}{l}\text { Fit } \\
\text { measures }\end{array}$} \\
\hline$\chi_{(d . f .)}^{2}$ & \multicolumn{2}{|l|}{$530_{(204)}$} & \multicolumn{2}{|l|}{$422_{(204)}$} & \multicolumn{2}{|l|}{$448_{(204)}$} \\
\hline RMSEA & \multicolumn{2}{|l|}{.052} & \multicolumn{2}{|l|}{.067} & \multicolumn{2}{|l|}{.061} \\
\hline $90 \% \mathrm{CI}_{\text {RMSEA }}$ & \multicolumn{2}{|l|}{$.046-.057$} & \multicolumn{2}{|l|}{$.056-.078$} & \multicolumn{2}{|l|}{$.054-.069$} \\
\hline$p_{\text {RMSEA }}$ & \multicolumn{2}{|l|}{.295} & \multicolumn{2}{|l|}{.006} & \multicolumn{2}{|l|}{.009} \\
\hline CFI & & \multicolumn{2}{|l|}{.972} & \multicolumn{2}{|l|}{.983} \\
\hline NFI & \multicolumn{2}{|l|}{.980} & \multicolumn{2}{|l|}{.947} & \multicolumn{2}{|l|}{.969} \\
\hline $\mathrm{RMR}^{\mathrm{s}}$ & \multicolumn{2}{|l|}{.027} & \multicolumn{2}{|l|}{.035} & \multicolumn{2}{|l|}{.026} \\
\hline \multicolumn{7}{|c|}{$\begin{array}{l}\text { Standard errors are in parentheses; } * * * p \leq .01, * * p \leq .05 \\
{ }^{a} \text { Values are calculated based on the restrictions } \gamma_{-1}=-\rho \gamma \text { and } \\
\beta_{-1}=-\rho \beta \text { of the autocorrelation model }\end{array}$} \\
\hline
\end{tabular}

Table 5: Parameter estimates and fit measures for the unrestricted ARDL model 


\begin{tabular}{|l|rrrrc|}
\hline Competing models & $\chi^{2}$ & d.f. & $\Delta \chi^{2}$ & $\Delta$ d.f. & $p$ \\
\hline Industrial Goods & 530.11 & 204 & - & - & - \\
$\quad$ unconstr. ARDL & 554.21 & 210 & 24.10 & 6 & .001 \\
AR1-RECEV & 535.90 & 207 & 5.79 & 3 & .122 \\
AR1-RECEV $_{\text {ROI }}$ & 546.65 & 206 & 16.54 & 2 & .000 \\
AR1-RECEV $_{\text {COST }}$ & 531.63 & 205 & 1.52 & 1 & .218 \\
AR1-RECEV $_{M S}$ & & & & & \\
Capital Goods & 421.70 & 204 & - & - & - \\
unconstr. ARDL $_{\text {AR1-RECEV }}$ & 444.69 & 210 & 22.99 & 6 & .001 \\
AR1-RECEV $_{R O I}$ & 426.81 & 207 & 5.11 & 3 & .164 \\
AR1-RECEV $_{C O S T}$ & 423.05 & 206 & 1.35 & 2 & .509 \\
AR1-RECEV $_{M S}$ & 438.13 & 205 & 16.43 & 1 & .000 \\
\hline Consumer Goods $_{\text {unconstr. ARDL }}$ & 448.14 & 204 & - & - & - \\
AR1-RECEV $_{\text {AR1-RECEV }}$ & 471.07 & 210 & 22.93 & 6 & .001 \\
AR1-RECEV $_{\text {COST }}$ & 458.77 & 207 & 10.63 & 3 & .014 \\
AR1-RECEV $_{M S}$ & 452.95 & 206 & 4.81 & 2 & .090 \\
\hline
\end{tabular}

Table 6: $\chi^{2}$ difference tests for the serial correlation hypothesis

For consumer goods instead, the changes are rather dramatically. Whereas time-invariant variables seem to decrease profitability for high-quality businesses (compare the results for the BM and the RECEV model in Tables 1 and 3), autocorrelated unobservables seem to greatly increase ROI, which leads to a quality effect which is indistinguishably different from zero once these effects are controlled. However, it should be pointed out that the serial correlation model was rejected for consumer goods, so that the interpretation (e.g., serial correlation vs. state dependence) of the autocorrelation coefficient for ROI remains ambiguous.

Except for industrial goods, the serial correlation hypothesis is rejected for the dependent variable market share (see the tests for AR1-RECEV ${ }_{M S}$ in Table 6). Since all coefficients for lagged quality are not significant, these results instead give support for the state dependence model. The role unobservable variables play in the relationship between quality and market share is obviously quite different from that in the profitability equation. The impact which product quality has on market share seems to be mediated by its influence on unobservable variables which might be subsumed under the notion "goodwill". However, it should be mentioned that these results are equally conformable with alternative models, for example a Koyck specification, which do not invoke the ex- 
istence of unobservable variables (Jacobson, 1990). Using the estimates for the current effect of product quality and the autoregressive coefficient for market share (see Table 5), the total effect of product quality on market share $\left(\gamma_{M S, Q U A}^{(T)}\right)$ can be approximated by the long-run multiplier $\left(\gamma_{M S, Q U A}^{(T)}=\gamma_{M S, Q U A} /\left(1-\rho_{M S}\right)\right)$. This leads to a total quality effect of .183 for capital goods and .151 for consumer goods, values relatively close to those of the baseline model, which represents the long-run relations between strategic factors and business performance.

\subsection{Conclusion}

In strategy research meanwhile some consensus exists that controlling for unobservable, firm-specific effects is of great relevance for empirical research on key success factors. Besides determining the "causal", typically short-term effects of these strategic factors, observing the influence of unobservable variables can provide important insides into the processes which lead to observed longterm relationships between strategic factors and business performance.

In this study, we propose a structural equation approach to control for time-invariant and autocorrelated unobservable variables based on panel data. Gradually extending a cross-sectional simultaneous equation model on the direct and indirect effects of product quality on profitability allows us to gauge how these different types of unobservables influence the relations in the model. We refrained from also controlling for transitory stochastic effects for several reasons. First of all, stochastic shocks, whose influence last only one period, seem relevant at most when the short-term "causal" effect of strategic factors is of interest, whereas we focused on the effects unobservable variables have on the long-term relationships between product quality, market share and ROI. This view is also supported by empirical evidence. As Ailawadi, Farris, and Parry (1999) have shown, controlling exclusively for temporary stochastic shocks only marginally alters the estimated impact of market share on the different components of ROI compared to a cross-sectional regression.

Second, even if one is interested in the short-term effect of strategic factors, the use of lagged values as instruments in an IV estimation of a first-difference model like equation (3) might lead to some methodological problems. Ideally, the instruments should be uncorrelated with the disturbances but highly correlated with the explanatory variables. Although the autocorrelations for data in levels is very high for many PIMS variables (e.g., market share, relative direct cost, product quality), this is not true for the time series of first differences. Likewise, also the correlation between first differences and lagged levels is rather low. For example, for a time series of market share from the PIMS SPIYR data base covering a period of six years ( $n=1141$ ), we found correlations between first differences and levels lagged two and three periods in the range of -.033 and .152. Under such conditions IV estimates might be seriously biased and highly imprecise (e.g., Bound, Jaeger, and Baker, 1995; Staiger and Stock, 1997). 
For an empirical application of our methodology we used data from the PIMS annual data base. Although it has to be taken into account that the number of variables in our model is rather limited, it can be concluded from the results that perceived product quality and market share, long emphasized by PIMS advocates as important drivers of profitability (Buzzell and Gale, 1987), remain relevant even if the influence of time-invariant and autoregressive firm-specific effects is controlled. For the three types of industries which were analyzed, quality drives ROI by increasing market share which in turn has a positive direct effect on profitability. Only for industrial goods the direct effect of product quality on profitability is still positive, an indication that customers are willing to pay a price premium for higher quality in this industry. To further explore how product quality is linked with higher profitability in the cross-sectional models, a component level analysis should be performed (Farris, Parry, and Ailawadi, 1992).

An interesting result of our study concerns the relationship between product quality and market share. Whereas typically the control of autocorrelated unobservables has been identified with the serial correlation model, the empirical results for the market share equation more favour the state dependence hypothesis. Thus, unobservable variables like "goodwill" are positively influenced by product quality which in turn improves the market share position.

\section{References}

Ailawadi, K. L., Farris, P. W., and Parry, M. E., Market Share and ROI: A Peek at Some Unobserved Variables. Technical Working Paper, Marketing Science Institute, Cambridge, 1993.

Ailawadi, K. L., Farris, P. W., and Parry, M. E., Market Share and ROI: Observing the Effect of Unobserved Variables. International Journal of Research in Marketing 16 (1999): 17-33.

Bagozzi, R. P., and Baumgartner, H., The Evaluation of Structural Equation Models and Hypothesis Testing, in Principles of Marketing Research, Bagozzi, R. P., ed., Basil Blackwell, Cambridge, 1994: 386-422.

Baltagi, B. H.: Econometric Analysis of Panel Data, Wiley, Chichester, 1995.

Barney, J. B., Strategic Factor Markets: Expectations, Luck, and Business Strategy. Management Science 32 (1986): 1231-1241.

Barney, J. B., Firm Resources and Sustained Competitive Advantage. Journal of Management 17 (1991): 99-120. 
Biggadike, R., The Risky Business of Diversification. Harvard Business Review 57, (May-June 1979): 103-111.

Bollen, K.A.: Structural Equations With Latent Variables, Wiley, New York, 1989.

Boulding, W., Unobservable Effects and Business Performance: Do Fixed Effects Matter?. Marketing Science 9 (1990): 88-91.

Boulding, W., Market-Driven Quality?. Working Paper No. 92-007, Wharton/PIMS Research Center, Pennsylvania, 1992.

Boulding, W., and Staelin, R., Environment, Market Share, and Market Power. Management Science 36 (1990): 1160-1177.

Boulding, W., and Staelin, R., A Look on the Cost Side: Market Share and the Competitive Environment. Marketing Science 12 (1993): 144-166.

Boulding, W., and Staelin, R., Identifying Generalizable Effects of Strategic Actions on Firm Performance: The Case of Demand-Side Returns to R\&D Spending. Marketing Science 14 (1995): G222-G236.

Bound, J., Jaeger, D. A., and Baker, R. M., Problems With Instrumental Variables Estimation When the Correlation Between the Instruments and the Endogenous Explanatory Variable is Weak. Journal of the American Statistical Association 90 (1995): 443-450.

Browne, M. W., and Cudeck, R., Alternative Ways of Assessing Model Fit, in Testing Structural Equation Models, Bollen, K.A., and Long, J. S., eds., Sage, Newbury Park, 1993: 136-162.

Buzzell, R. D., Commentary on "Unobservable Effects and Business Performance". Marketing Science 9 (1990): 86-87.

Buzzell, R. D., and Gale, B. T.: The PIMS Principles: Linking Strategy to Performance, Free Press, New York, 1987.

Camerer, C. F., Redirecting Research in Business Policy and Strategy. Strategic Management Journal 6 (1985): 1-15. 
Camerer, C. F., Fahey, L. (1988), The Regression Paradigm: A Critical Appraisal and Suggested Directions, in Strategic Management Frontiers, Grant, J., ed., JAI Press, Greenwich, 1988: 443459.

Capon, N., Farley, J. U., and Hoenig, S., Determinants of Financial Performance: A Meta-Analysis. Management Science 36 (1990): 1143-1159.

Charnes, A., Cooper, W. W., and Rhodes, E., Measuring the Efficiency of Decision Making Units. European Journal of Operational Research 2 (1978): 429-444.

Farris, P. W., Parry, M. E., and Ailawadi, K. L., Structural Analysis of Models with Composite Dependent Variables. Marketing Science 11 (1992): 76-94.

Ghemawat, P.: Commitment: The Dynamic of Strategy, Free Press, New York, 1991.

Godfrey, P. C., and Hill, C. W. L., The Problem of Unobservables in Strategic Management Research. Strategic Management Journal 16 (1995): 519-533.

Grant, R. M., The Resource-Based Theory of Competitive Advantage: Implications for Strategy Formulation. California Management Review 33 (1991): 114-135.

Griliches, Z., Errors in Variables and Other Unobservables. Econometrica 42 (1974): 971-998.

Grunert, K. G., and Ellegaard, C., The Concept of Key Success Factors: Theory and Method, in Perspectives on Marketing Management, vol. 3, Baker, M. J., ed., Wiley, Chichester, 1993: 245274.

Hildebrandt, L., and Annacker, D., Panelanalysen zur Kontrolle “unbeobachtbarer” Einflussgrössen in der Erfolgsfaktorenforschung. Zeitschrift für Betriebswirtschaft 66 (1996): 1409-1426.

Hildebrandt, L., and Buzzell, R., Product Quality, Market Share, and Profitability: A Causal Modeling Approach. Working Paper 91-045, Harvard Business School, Cambridge, 1991.

Hsiao, C.: Analysis of Panel Data, Cambridge University Press, Cambridge, 1986.

Hu, L., and Bentler, P. M., Fit Indices in Covariance Structure Modeling: Sensitivity to Underparameterized Model Misspecification. Psychological Methods 3 (1998): 424-453. 
Hu, L., and Bentler, P. M., Cutoff Criteria for Fit Indexes in Covariance Structure Analysis: Conventional Criteria versus New Alternatives. Structural Equation Modeling 6 (1999): 1-55.

Itami, H., and Roehl, T. W.: Mobilizing Invisible Assets, Harvard University Press, Cambridge, 1987.

Jacobson, R., Distinguishing Among Competing Theories of the Market Share Effect. Journal of Marketing 52 (October 1988): 68-80.

Jacobson, R., Unobservable Effects and Business Performance. Marketing Science 9 (1990): 74-85.

Jacobson, R. (1992), The “Austrian” School of Strategy. Academy of Management Review 17 (1992): 782-807.

Jacobson, R., and Aaker, D., Is Market Share All That It's Cracked Up To Be?. Journal of Marketing 49 (Fall 1985): 11-22.

Jacobson, R., and Aaker, D. A., The Strategic Role of Product Quality. Journal of Marketing 51 (October 1987): 31-44.

Jaworski, B. J., and Kohli, A. K., Market Orientation: Antecedents and Consequences. Journal of Marketing 57 (July 1993): 53-70.

Jöreskog, K. G., An Econometric Model for Multivariate Panel Data, Annales de l'INSEE 30-31 (1978): 355-366.

Jöreskog, K. G., and Sörbom, D.: LISREL 8: User's Reference Guide, Scientific Software, Chicago, 1996.

Lillard, L. A., and Willis, R. J., Dynamic Aspects of Earning Mobility. Econometrica 46 (1978): 985-1012.

Mosakowski, E., Managerial Prescriptions Under the Resource-Based View of Strategy: The Example of Motivational Techniques. Strategic Management Journal 19 (1998): 1169-1182.

Murthi, B. P. S., Srinivasan, K., and Kalyanaram, G., Controlling for Observed and Unobserved Managerial Skills in Determining First-Mover Market Share Advantages. Journal of Marketing Research 33 (1996): 329-336. 
Muth, J. F., Rational Expectations and the Theory of Price Movements. Econometrica 29 (1961): 315-335.

Narver, J. C., and Slater, S. F., The Effect of a Market Orientation on Business Profitability. Journal of Marketing 54 (October 1990): 20-35.

Peteraf, M. A., The Cornerstones of Competitive Advantage: A Resource-Based View. Strategic Management Journal 14 (1993): 179-191.

Peters, T. J., and Waterman, R. H.: In Search of Excellence, Harper Collins, New York, 1982.

Phillips, L. W., Chang, D. R., and Buzzell, R. D., Product Quality, Cost Position and Business Performance: A Test of Some Key Hypotheses. Journal of Marketing 47 (Spring 1983): 26-43.

Porter, M. E., The Contributions of Industrial Organization to Strategic Management. Academy of Management Review 6 (1981): 609-620.

Priem, R. L., and Butler, J. E., Is the Resource-Based "View" a Useful Perspective for Strategic Management Research?. Academy of Management Review 26 (2001): 22-66.

Rouse, M. J., and Dällenbach, U. S., Rethinking Research Methods for the Resource-Based Perspective: Isolating Sources of Sustainable Competitive Advantage. Strategic Management Journal 20 (1999): 487-494.

Rumelt, R. P., and Wensley, R., In Search of the Market Share Effect, Working Paper MGL-61, University of California, Los Angeles, 1980.

Rumelt, R. P., Schendel, D., and Teece, D. J., Strategic Management and Economics. Strategic Management Journal 12 (1991): 5-29.

Sousa de Vasconcellos, J. A., and Hambrick, D. C., Key Success Factors: Test of a General Theory in the Mature Industrial-Product Sector. Strategic Management Journal 10 (1989): 367-382.

Staiger, D., and Stock, J. H., Instrumental Variables Regression With Weak Instruments. Econometrica 65 (1997): 557-586.

Teece, D. J., Pisano, G., and Shuen, A., Dynamic Capabilities and Strategic Management. Strategic Management Journal 18 (1997): 509-533. 
Wensley, R., PIMS and BCG: New Horizons or False Dawn?. Strategic Management Journal 3 (1982): 147-158.

Wernerfelt, B., A Resource-based View of the Firm. Strategic Management Journal 5 (1984): 171180. 